Our Nature (2011) 9: 168-172

\title{
Studies on Length-weight and Length-length Relationships of a Cold Water Fish Neolissochilus hexagonolepis (McClelland) from Tamor River, Nepal
}

\author{
S. Subba ${ }^{1}$ and S. Adhikaree ${ }^{2^{*}}$ \\ ${ }^{1}$ Department of Zoology, Dhankuta Multiple Campus, T.U., Dhankuta, Nepal \\ ${ }^{2}$ Department of Zoology, P.G. Campus, T.U., Biratnagar, Nepal \\ *E-mail:saligramadhikaree@yahoo.com
}

Received: 28.10.2011, Accepted: 20.11.2011

\begin{abstract}
Present paper attempts to describe length-weight (LW) and total length-standard length (TL and SL) total length and forkal length relationships of cold water fish Neolissochilus hexagonolepis. Fish of different length and weight were caught using cast net and scoop net at Mulghat vicinity, Dhankuta. The fish were kept in ice box in fresh condition and brought to fish laboratory, Department of Zoology, Post Graduate Campus, Biratnagar .The measurement of the fish samples was done with maximum accuracy. The data obtained from measurement were analysed using the formula $\mathrm{W}=$ $\mathrm{aL}^{\mathrm{b}}$. The $\mathrm{b}$ values estimated for the total length and standard length in relation to body weight were 3.056 and 3.063 , respectively. The values of b clearly indicate the isometric growth pattern.For total length, standard length and forkal length relationships, the linear values of $b$ were 0.103 and -0.299 . Similarly for the relationship between the forkal length and standard length the linear value of $b$ was 0.346 .
\end{abstract}

Key words: Neolissochilus hexagonolepis, length-weight relationship, length-length relationship.

\section{Introduction}

The torrential river fish Neolissochilus hexagonolepis (McClelland) is commonly known as Copper Mahseer and locally 'Katle. It is one of the beautiful game fishes of Nepal. The study of length-weight and length-length relationships is paramount important and widely practiced tool in the fishery for different purposes, especially in the study of population dynamics, ecology, taxonomic differences, event in life history like metamorphosis, maturity, stock management (Le Cren, 1951; Lagler et al., 1962; Froese, 2006; Abdoli et al., 2008; Ferreira et al., 2008; Vaslet et al., 2008; Epler et al., 2009). In fishes, generally the growth pattern follows the cube laws
(Brody, 1945; Lagler, 1952) but the actual relationship may depart from this (Le Cren, 1951), either due to environmental factors or some other reasons. The relationship is generally expressed by the equation, $\mathrm{W}=$ $\mathrm{aL}^{\mathrm{b}}$.

Several workers have studied lengthweight and length-length relationships of fishes living in different environmental conditions. Le Cren (1951) gave an account of the length-weight relationship and seasonal cycle in gonad weight and condition factor in the Perch (Perca fluviatilis). The works of Thakur and Das (1974), Subba and Ghosh (2000), Subba and Pandey (2000), Abdallah (2002), Somro et 


\section{S. Subba and S. Adhikaree / Our Nature (2011) 9: 168-172}

al. (2007), Kara and Bahar (2008), Nowak et al. (2009), Ansumala and Subba (2009), Subba et al. (2009) have given an account of length-weight and length-length relationsips of the following fishes viz., Heteropneustes fossilis, Mugil cephalus, Moemacheilus triangularis, Lepidocephalus thermalls, Cirrhinus mrigala, Puntius sarana, Barilus bendelisis and B. vagna, Glyptothorax telchitta, Botia lohachata Leuciscus leuciscus, Phoxinus phoxinus, Salmo trutta, Boops boops, Eutropiichthyes vacha, Schistura rupicola and Gudusia godanahiae, respectively.

The present study is an attempt to estimate and impart lacking information about length-weight and length-length relationships of torrential river fish $N$. hexagonolepis.

\section{Materials and methods}

Fishes of varied length and weight were caught using cast net at Mulghat vicinity in Tamor river of Dhankuta. The fishes were kept in ice box in fresh condition and brought to the fish laboratory of Zoology Department, Post Graduate Campus, Biratnagar. The fish samples were collected from July, 2007 to June, 2008. The fishes were measured, in full stretched condition, to the nearest $0.2 \mathrm{~cm}$ and weighed to the nearest $0.2 \mathrm{~g}$, after removing moisture from their body using towels of paper and cloth. The standard length measurement was taken from the tip of the stout to the base of the tail in $\mathrm{cm}$. Similarly, forkal length was measured from the tip of the snout to the forked point of the caudal fin.

The weight of fish specimens ranged from 2.4 to $72.9 \mathrm{~g}$, maximum total length was $20.5 \mathrm{~cm}$ and minimum $6.2 \mathrm{~cm}$. Similarly, maximum standard length was $16.3 \mathrm{~cm}$ and minimum $5.0 \mathrm{~cm}$ and maximum forkal length 17.5 and minimum $5.4 \mathrm{~cm}$. The data obtained from the measurements were computed for regression and correlation coefficient values in case of length-weight and length-length relationships. An application of logarithmic transformation of the data was made to establish the relationship equation by least square method.

\section{Results}

The weight of $N$. hexagonolepis showed clear cut increasing trend with the increase in body length. When logarithmic values of weight were plotted on the co-ordinate (Yaxis) against those of respective length on the abscissa (X-axis) they always gave straight line (Figs. 1, 2, 3).

The computed regression coefficient (b) values for the relationships between weight and lengths i.e., total length and the standard length came to be more than 3 i.e., 3.056 and 3.063, respectively. The relationship equations are as follows:

1. For total length:

$\mathrm{Wt}=0.008 \mathrm{TL}^{3.056}$

or $\log \mathrm{Wt}=-2.096+3.056 \log \mathrm{TL}$

2. For standard length:

$\mathrm{Wt}=0.016 \mathrm{SL}^{3.063}$

or $\log \mathrm{Wt}=-1.79+3.063 \log \mathrm{SL}$

3. For forkal length

$\mathrm{Wt}=0.010 \mathrm{x}^{3.138}$

or $\log \mathrm{Wt}=-2+3.138$

The linear value of $b$ came to be $0.102,-0.299$ and 0.346 , respectively for the relationships of total length with standard length and forkal length and, forkal length with standard length.

The computed values for coefficient of determination ' $r$ ' ' for all the relationships i.e., total length-weight (TL-Wt), standard length-weight (SL-Wt) and forkal length- 


\section{S. Subba and S. Adhikaree / Our Nature (2011) 9: 168-172}

weight (FL-Wt.) were $0.980,0.986$ and 0.986 , respectively (Figs. 1, 2, 3). Similarly, the value of ' $\mathrm{r}^{21}$ for total length-standard length (TL-SL), total length-forkal length (TL-FL) and forkal length- standard length (FL-SL) were 0.990, 0.996 and 0.994, respectively.

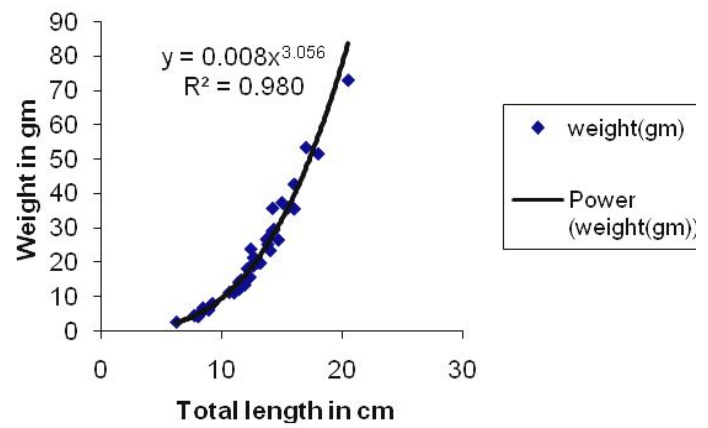

Figure 1. Relationships between total length (TL) and weight $(\mathrm{Wt})$

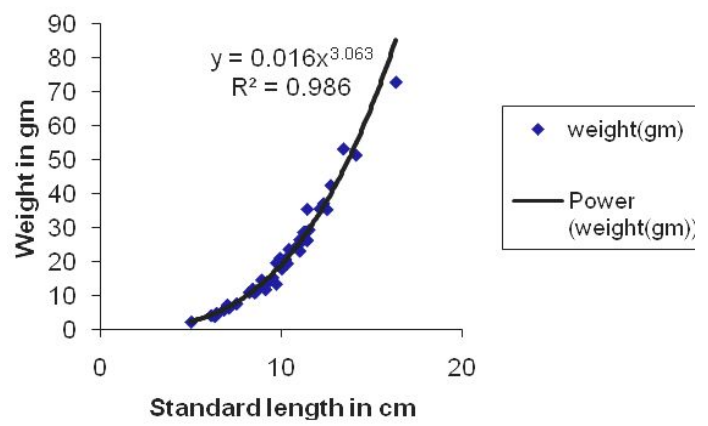

Figure 2. Relationships between standard length (SL) and weight $(\mathrm{Wt})$

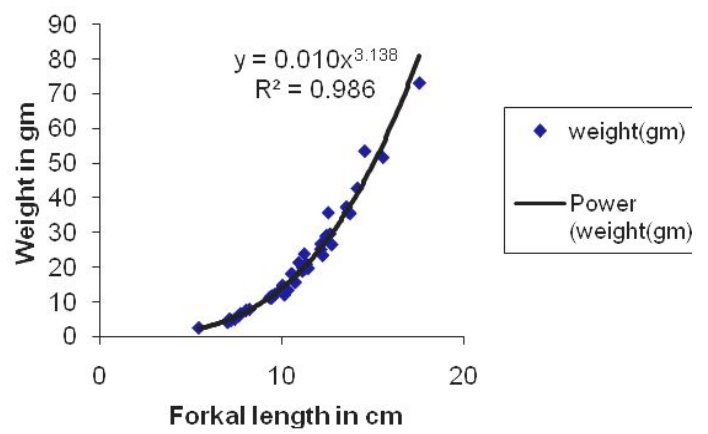

Figure 3. Relationships between forkal length (FL) and weight (Wt)

\section{Discussion}

Several workers have made estimations on length-weight and length-length relationships in different fish species. Le Cren (1951) has stated that the lengthweight relationship in fishes are probably related to the seasonal variation since fat and water content of fish may vary according to temperature The change in ' $b$ ' value shows allometric growth of the body due to the influence of numerous factors viz., seasonal fluctuations, change in physiological condition during spawning periods, gonad development, sex, physicochemical conditions of the environment and nutrition conditions of the environment (Sinha, 1973). The reported exponent values for ' $b$ ' for different fishes ranged between 2.5 to 4.0 (Hile, 1936; Martin, 1949) and 2 to 4 (Bagenal and Tesch, 1978; Koutrakis and Tsikliras, 2003). Sekharan (1998) have also observed an inter-specific for ' $b$ ' that remains constant at ' 3.0 ' for an ideal fish. In the present fish sample, the calculated values for ' $b$ ' for length and weight were higher than 3, i.e., 3.2202 and 3.2559 which were of expected range and indicated that the growth is nearly isometric in $N$. hexagonolepis. Similar differences in slope value have been reported by Pandey et al. (1974), Thakur and Das (1974), Subba and Ghosh (2000), Subba and Pandey (2000), Ansumala and Subba (2009), Subba et al. (2009) on Heteropneustes fossilis, Glyptothorax telchitta, Schistura rupicola and Gudusia godanahiae. Le Cren (1951) states that the length weight relationship in fishes is probably related to the seasonal variations as fishes do not retain the same shape or body contour through out the year. So there should be slight change in slope values in different seasonal studies. The values of coefficient 


\section{S. Subba and S. Adhikaree / Our Nature (2011) 9: 168-172}

of determination ' $\mathrm{r}$ ', calculated for all relationships viz., TL-Wt, SL-Wt. and FLWt. and TL-SL,TL-SL and FL-SL in cold water fish $N$. hexagonolepis (Figs. 1, 2, 3) were $0.980,0.986$ and 0.986 and 0.990 , 0.996 and 0.994 , respectively which are highly significant $(\mathrm{p}<0.001)$.

\section{Acknowledgements}

A professional fisherman M.B. Majhi of Mulghat deserves special thanks for his valuable help for catching fishes of different sizes as per need.

\section{References}

Abdallah, M. 2002. Length-weight relationship of fishes caught by trawl of Alexandria Egypt. Naga, the ICLARM Quarterly 25(1): 19-20.

Abdoli, A., P. Rasooli and H. Mostafavi 2008. Length-weight relationships of Capoeta capoeta capoeta (Guldenstaedt, 1772) in the Gorganrud River, South Caspian Basian. J. Appl. Ichthyol. 24: 96-98.

Ansumala, A. and B.R. Subba 2009. Studies on length-weight relationship of a hillstream loach, Schistura rupicola (McClelland). J. Nat. Hist. Mus. 24: 126-129.

Bagenal, T. and F.W. Tesch 1978. Age and growth. Method for assessment of fish production in freshwater. IBP Handbook, (Ed. T. Bagenal), Blackwell Scientific Press, Oxford.

Brody, S. 1945. Bioenergetics and growth. Reinhold Publishing Corporation, New York. 1023 p.

Epler, P., M. Nowak and W. Popek 2009. Growth rate of the chub (Squalius cephalus) and the nase (Chondrostoma nasus) from Raba, Dunajec and Poprad river-AACL Bioflux 2: 1-8.

Ferreira, S., R. Sousa, J. Delgado, D. Carvalho and T. Chada 2008. Weight-length relationships for demersal fish species caught off the Madeira archipelago (eastern-central Atlantic). J. Appl. Ichthyol. 24: 93-95.

Froese, R. 2006. Cube law, condition factor and weight-length relationships: history, meta-analysis and recommendations. J. Appl. Ichthyol. 22: 241253.
Hile, R. 1936. Age and growth of the Cisco, Leucichys artedi (Le sueur) in the lakes of the north-eastern highlands. Wisconsin Bull. U.S. Bur. Fish. 8: 311-317.

Kara, A. and B. Bahar 2008. Length-weight and length-length relationships of the bogue Boops boops (Linneaus, 1758) in Izmir Bay (Aegean Sea of Turkey). Belg. J. Zool. 138(2): 154-157.

Koutrakis, E.T. and A.C. Tsikliras 2003. Lengthweight relationships of fishes from three northern Aegean estuarine systems (Greece). J. Appl. Ichthyol. 19: 258-260.

Lagler K.F., J.E. Bardach and R.R. Miller 1962. Ichthyology. John Wiley and Sons, Inc., New York. $546 \mathrm{p}$.

Lagler, K.F. 1952. Freshwater fishery biology. W.M.C. Brown Company, Dubyqu. Iowa

Le Cren, E.D. 1951. The length-weight relationships and seasonal cycle in gonad weight and condition in the perch (Perca fluviatilis). J. Anim. Ecol. 20: 201-219.

Martin, W.R. 1949. The mechanics of environmental control of body form in fishes. Univ. Toronto stud. Biol. 58, Ont. Fish. Res. Lab.70: 1-91.

Nowak, M., P. Wlodzimierz, J. Wojciech, D. Stanislaw, P. Jakub, K. Krzysztof and E. Piotr 2009. Weight-length relationships for three fishes (Leuciscus leuciscus, Phoxinus phoxinus, Salmo trutta) from the Strwiaz river (Dniester River Drainage). Arch. Pol. Fish 17: 313-316.

Pandey, B.N., B.J. Choubey and J.S. Dutta Munshi 1974. Studies on some aspects of an air-breathing fish Heteropneustes fossilis (Bloach). Ind. J. Zool. 15(2): 79-86.

Sekharan, K.V. 1998. On the catfish resources of the coasts of Andhra Pradesh, Orissa and West Bengal. In Proceedings of the symposium on living resources of the seas round India, Cochin. pp. $517-536$

Sinha, A.L. 1973. Length-weight relationship of a freshwater catfish, Clarias batrachus (Linn.). Ind. J. Zool. 14(2): 97-102.

Soomro, A.N., W.A. Baloch, S.I.H. Jafri and H. Sujuki 2007. Studies on length-weight and lengthlength relationships of catfish, Eutropichthyes vacha Hamilton (Schibeidae: Siluriformes) from Indus river, Sindh, Pakistan. Caspian J. Env. Sci. 5(2): 134-135. 


\section{S. Subba and S. Adhikaree / Our Nature (2011) 9: 168-172}

Subba, B.R. and M.R. Pandey 2000. Length-weight relationship of Botia lohachata (Chand) from the Saptakoshi river, Nepal. J. Nat. His. Mus 19: 8387.

Subba, B.R. and T.K. Ghosh 2000. Length-weight relationship of a hill-stream fish Glyptothorax telchitta (Ham.) from Saptakoshi river of Nepal. $J$. Ind. Fisheries Associations 27: 79-82.

Subba, B.R., R.P. Bhagat and S. Adhikaree 2009. Studies on length-weight and length-length relationships of a freshwater fish Gadusia godanahiae from Biratnagar, Nepal. Our Nature 7: 218-221.

Thakur, N.K. and N.K. Das 1974. Length-weight relationship of Heteropneustes fossilis (Bloch). J. Inland Fish. Soc., India. 6: 95-96.

Vaslet, A., Y. Bouchon-Navaro, M. Louis and C. Bouchon 2008. Weight-length relationships for 20 species collected in the mangroves of Guadeloupe (Lesser Antiles). J. Appl. Ichthyol. 24: 99-100. 